\title{
Дивидендная политика компаний на развивающихся рынках
}

\author{
Пирогов Н.К. ${ }^{10}$, Волкова Н.Н. ${ }^{11}$
}

В статье представлень результаты эмпирического исследования дивидендной политики компаний таких крупных развивающихся рынков, как Россия, Индия и Китай, в период с 1995-го по 2008 год. Результать исследования показали, что дивидендная политика каждого развивающегося рынка индивидуальна и ключевые драйверы в ее определении различны. Дивидендная политика компаний в до- и посткризисные периоды (дефолт в России в 1998 году, азиатский кризис 1997-1999 г2.) определяется различными факторами. В докризисный период дивидендная политика определялась рентабельностью компании и носила более комплексный характер в посткризисный период. Более того, в докризисный период все отклонения в дивидендной политике от средней тенденции по стране объясняются случайными факторами, а не индивидуальностью и определенными характеристиками фирмы.

$J E L: G 35, C 23$

Ключевые слова: дивидендная политика, БРИК, развивающцеся рынки, панельный анализ данных.

\section{Введение}

Основной задачей фирмы является увеличение стоимости для ее собственников. От политики выплат владельцам капитала, основу которой традиционно составляла дивидендная политика, зависит, насколько динамика развития компании отражает изменение благосостояния ее собственников. Дивидендной политикой фирмы является комплекс решений об определении размера, сроков и порядка выплаты дивидендов.

Компании выплачивают значительные суммы в качестве дивидендов: так, в США в 2007 и 2008 гг. в качестве дивидендов выплачивалось более 200 млрд долларов, что составляет 1,5\% от ВВП США и (для сравнения) более чем в 2 раза превышает суммарный ВВП всей Прибалтики (Литвы, Латвии и Эстонии). В Англии за те же периоды эта цифра составила более 50 млрд фунтов стерлингов в год. Статистика развивающихся рынков также подчеркивает значительность дивидендных выплат: в Китае в 2007 г. более 40\% компаний, прошедших листинг на бирже, выплачивали дивиденды, общая сумма которых приблизилась к 35 млрд долларов США; крупнейшие российские компании («Газпром», «Лукойл», «Норильский никель» и т.д.) в среднем за последние 3 года ежегодно выплачивали в форме дивидендов более 1 млрд долларов.

Десятки исследований посвящены детерминантам дивидендной политики компании, но, несмотря на это, консенсус в этом вопросе до сих пор не достигнут.

Фама и Фрэнч; Айвазян и др.; Нэсер и др. [Fama and French, 2001; Aivazian et al., 2003; Naceur et al., 2006] провели общее исследование детерминант дивидендной политики. Миллер и Рок; Джон и Вильямс; Ален и Михаели [Miller and Rock, 1985; John and Williams, 1985; Allen and Michaely, 2003] в качестве основной роли дивидендов выделяют сигнальную роль, которую подвергают сомнению ДэАнжело и др.; Истербрук; Ла Порта и др.; Савики [DeAngelo et al., 2004; Easterbrook, 1984; La Porta et al., 2000; Sawicki, 2009] уделили особое внимание влиянию агентской проблемы на дивидендную политику. В дополнение к

\footnotetext{
${ }^{10}$ Старший преподаватель кафедры экономики и финансов фирмы ГУ ВШЭ.

11 Участник исследовательского проекта (GAP-project) в Берлинской школе права и экономики, магистр ГУВШЭ.
} 
большому количеству эмпирических исследований Бакер и др.; Брэв и др. [Baker et.al., 2001; Brav et al., 2005] исследовали детерминанты дивидендной политики, базируясь на результатах опросов менеджеров компаний.

Основными вопросами, которыми интересуется как академическое сообщество, так и топ-менеджмент компаний, являются оптимальный размер и форма, которую должны принимать выплаты собственникам. Долгое время основным источником выплат владельцам капитала были дивидендные выплаты, однако с середины 80-х годов XX века все большую популярность на развитых рынках стали набирать выплаты в форме обратного выкупа акций. Ален и Михаели [Allen, Michaely, 2003] показали, что в США в 1998 г. впервые объемы обратного выкупа акций превысили дивидендные выплаты. На развивающихся рынках инструмент обратного выкупа акций находится в стадии развития.

В работах по дивидендной политике на развивающихся рынках, как правило, авторы акцентировали свое внимание на одной конкретной стране, что не позволяло обобщать выводы автора на все развивающиеся страны. В случае большой выборки стран каждая страна представлена небольшим количеством компаний, что не позволяло выявить тенденции и отличия конкретной страны, если они существуют.

В данной работе исследуются внутренние и внешние факторы, оказывающие влияние на дивидендную политику. К внешним макроэкономическим факторам можно отнести развитость фондового рынка и банковской системы, реальную процентную ставку, ставку налога. К внутренним факторам относится рентабельность, размер и темпы роста компании, ее инвестиционные возможности и финансовые ограничения.

Для проведения эмпирического исследования была сформирована выборка компаний из России, Индии и Китая. Исследуемый период, 1995-2008 гг., позволил отследить изменения в дивидендной политике в посткризисный период (дефолт в России в 1998 г., азиатский кризис 1997-1999 гг.). Основным методом исследования являлся панельный анализ данных.

\section{Дивидендная политика компаний в настоящее время}

Несмотря на то что дивиденды, как правило, облагаются по более высокой ставке налога, чем доходы от прироста капитала, в случае обратного выкупа акций как многие компании, так и собственники предпочитают дивиденды в качестве основной формы выплат акционерам.

Брэв и др. [Brav et al., 2005] в своем исследовании показали, что даже в случае, если дивиденды с налоговой точки зрения менее эффективны, чем обратный выкуп акций, налоги играют второстепенную роль. По результатам интервью Брэв и др. [Brav et al., 2005], только $21,1 \%$ респондентов (все респонденты принадлежат к менеджменту компаний) отметили, что налоговая ставка, которой облагаются инвесторы, является важным фактором, влияющим на их решения о дивидендах. Аналогично только 29,1\% фирм, осуществляющих обратный выкуп акций, отметили подоходные налоги как важный фактор, влияющий на объем выкупаемых акций.

На вопрос о том, повлияет ли неэффективность дивидендов с налоговой точки зрения, по сравнению с обратным выкупом акций, на их решение об обратном выкупе, 41,8\% респондентов ответили, что примут это решение во внимание. В большинстве своем менеджеры отмечают, что принимают во внимание различие в налоговых ставках, но это не является первоочередным фактором, влияющим на их решение о дивидендной политике. Брэв и др. [Brav et al., 2005] также утверждают, что по результатом опроса акционеров компаний было также выявлено, что налоговая ставка не является ключевым фактором, на основании которого принимается решение об уменьшении доли бумаг с высокими дивидендами.

Фама и Фрэнч [Fama and French, 2001] обнаружили, что три основные характеристики влияют на решение фирмы платить дивиденды, а именно уровень рентабельности, 
инвестиционные возможности и размер компании. Более крупные и рентабельные компании c большей вероятностью будут платить дивиденды. Наличие возможностей для инвестирования снижает вероятность выплаты дивидендов.

Согласно результатам Фама и Фрэнч [Fama and French, 2001], американские компании, которые никогда не платили дивиденды, как правило, менее рентабельны, чем компании, которые выплачивают дивиденды, но при этом осуществляют больший объем инвестиций, больше вкладывают в исследования и разработки $(\mathrm{R} \& \mathrm{D})$ и имеют более высокое отношение рыночной стоимости активов к их балансовой стоимости (Q Тобина). Объем инвестиций компаний, выплачивающих дивиденды, обычно находится на уровне прибыли до вычета процентов; инвестиции же фирм, не выплачивающих дивиденды, как правило, превышают размер прибыли. Что же касается размера компаний, то те, которые выплачивают дивиденды, в несколько раз больше компаний, которые их не выплачивают.

\section{Дивидендная политика на развивающихся рынках}

Айвазян и др. [Aivazian et al., 2003] сравнил дивидендную политику развивающихся рынков и США и получил результаты, согласно которым дивидендная политика развивающихся стран объясняется теми же переменными, что и дивидендная политика американских компаний, а именно их уровнем прибыльности, уровнем долга и отношением рыночной стоимости к балансовой (market-to-book ratio). Однако степень влияния этих переменных на дивидендную политику в США и на развивающихся рынках разная. Выборка Айвазян и др. [Aivazian et al., 2003] включала в себя 8 стран: Иорданию, Пакистан, Зимбабве, Индию, Корею, Малайзию, Турцию и Таиланд.

Айвазян и др. [Aivazian et al., 2003] показал, что с увеличение рентабельности (где ROE является прокси для уровня рентабельности компании) увеличивается уровень дивидендов, что является подтверждением теории остаточного денежного потока (residual cash flow theory) о дивидендах. Более высокий уровень долга соответствует более низким дивидендным выплатам, что позволяет автору заключить, что финансовые ограничения оказывают влияние на дивидендную политику. Отношение рыночной стоимости компании к ее балансовой стоимости, бизнес-риск и размер компании также оказывают влияние на ее дивидендную политику.

Особенности каждой конкретной страны влияют на дивидендную политику ее компаний, что отражается в значимости дамми-переменных для каждой страны в оцениваемой модели. Интересным результатом Айвазян и др. [Aivazian et al., 2003], которому автор так и не смог найти объяснение, является тот факт, что уровень дивидендов, выплачиваемых развивающимися странами, превышает уровень дивидендов, выплачиваемых американскими компаниями.

Нэсер и др. [Naceur et al., 2006] исследовали дивидендную политику 48 фирм фондовой биржи Туниса в период с 1996-го по 2002 г.: 29 фирм из выборки являются предприятиями регулируемых отраслей (транспорт, финансовый и телекоммуникационный сектор). В регулируемых и нерегулируемых отраслях решения о выплате дивидендов могут приниматься на основе разных факторов, поэтому авторы ввели дамми-переменную, которая будет учитывать данные различия.

В своем исследовании авторы оценивали две модели. Первая являлась модифицированной моделью Линтнера [Lintner, 1956]. Результаты тестирования данной модели показали, что фирмы Туниса, определяя свои дивидендные выплаты, опираются как на текущую прибыль, так и на прошлые дивиденды, при этом размер выплачиваемых дивидендов в текущий период более чувствителен к уровню текущей прибыли, чем к уровню дивидендов, выплаченных в прошлый период.

Вторая модель включает в себя прокси для уровня прибыльности компании, концентрации собственности, размера, финансового рычага и ликвидности акций компании. Контрольными переменными в модели также являются темп роста активов фирмы и 
отношение рыночной стоимости к балансовой стоимости собственного капитала, данные переменные являются прокси для отслеживания сигнальных стимулов фирмы. Нэсер и др. [Naceur et al., 2006] обнаружил, что более стабильные и прибыльные фирмы за счет более значительного потока свободных денежных средств могут позволить себе выплачивать более высокие дивиденды. При этом быстрорастущие компании также выплачивают более высокие дивиденды, что подтверждает сигнальную теорию о дивидендах. Ликвидность и размер фирмы отрицательно связаны с уровнем дивидендных выплат. Нэсер и др. [Naceur et al., 2006] не обнаружил связи между концентрацией собственности, финансовым рычагом и дивидендной политикой компании.

Рэдди и Рэф [Reddy and Rath, 2005] исследовал дивидендную политику индийских компаний в период с 1991-го по 2001 г. Автор констатирует, что доля компаний, выплачивающих дивиденды, упала с 57\% в 1991 г. до 32\% в 2001-м. Компании, выплачивающие дивиденды, как правило, больше и являются более прибыльными по сравнению с компаниями, которые не выплачивают дивиденды. Согласно результатам, полученным автором, возможности роста индийских компаний не влияют на их дивидендную политику. Обратный выкуп акций как альтернативный способ выплат акционерам не рассматривался в данном исследовании, так как обратный выкуп акций был разрешен в Индии с 1998 г. и, по утверждению автора, использовался компаниями исключительно редко.

Омрэн и Пойнтон [Omran and Pointon, 2004] исследовали выборку египетских фирм. Леверидж и размер фирмы оказывают наибольшее влияние на дивидендную политику фирмы. Результат, полученный авторами, говорит о том, что египетские фирмы при финансировании проектов предпочтут долг использованию нераспределенной прибыли в ущерб выплате дивидендов. Маленькие фирмы выплачивают меньше дивидендов. Авторы использовали q-ratio как прокси для инвестиционных возможностей фирмы и получили различные результаты для двух подвыборок активно и неактивно торгующихся фирм. Активно торгующиеся фирмы с высокими инвестиционными возможностями уменьшают дивиденды, для того чтобы финансировать инвестиционные проекты высвободившимися денежными средствами. Неактивно торгующиеся фирмы не уменьшают размер дивидендов при наличии проектов для инвестирования.

Стимулом для увеличения размера выплачиваемых дивидендов среди египетских фирм в первую очередь является увеличение операционной прибыли до налогообложения. В случае же принятия решения о снижении размера дивидендов ключевым фактором становится ликвидность компании, уровень прибыли в данном случае является следующим по степени значимости фактором.

Эдэоглу [Adaoglu, 2000] исследовал дивидендную политику турецких компаний и заключил, что она, в отличие от дивидендной политики развитых рынков, нестабильна и в первую очередь зависит от уровня текущей прибыли.

\section{Описание выборки и дескриптивный анализ}

Целевыми странами для исследования изначально были страны БРИК, однако в силу того что в Бразилии законодательно наложено обязательство выплачивать дивиденды всем компаниям, декларирующим положительные прибыли, выборка была сокращена до России, Индии и Китая.

Для исследования были отобраны только те компании, которые выплачивали дивиденды. Компании финансового сектора были исключены. Исследуемый период 1995-2008 гг. За более ранний период в выбранных странах данные о дивидендах отсутствуют. За 2008 г. в выборку входят наблюдения по 43 российским, 848 индийским и 716 китайским компаниям.

Структурные различия в моделях могут приходиться на период до и после кризисов в рассматриваемых странах. Азиатский кризис, начавшийся в июле 1997 г., незначительно 
затронул Китай и Индию. Индийская экономика пережила в этот период большие потрясения по сравнению с китайской, что отразилось в скачке ее валютного курса и снижении темпов роста ВВП на душу населения (рис 1.).

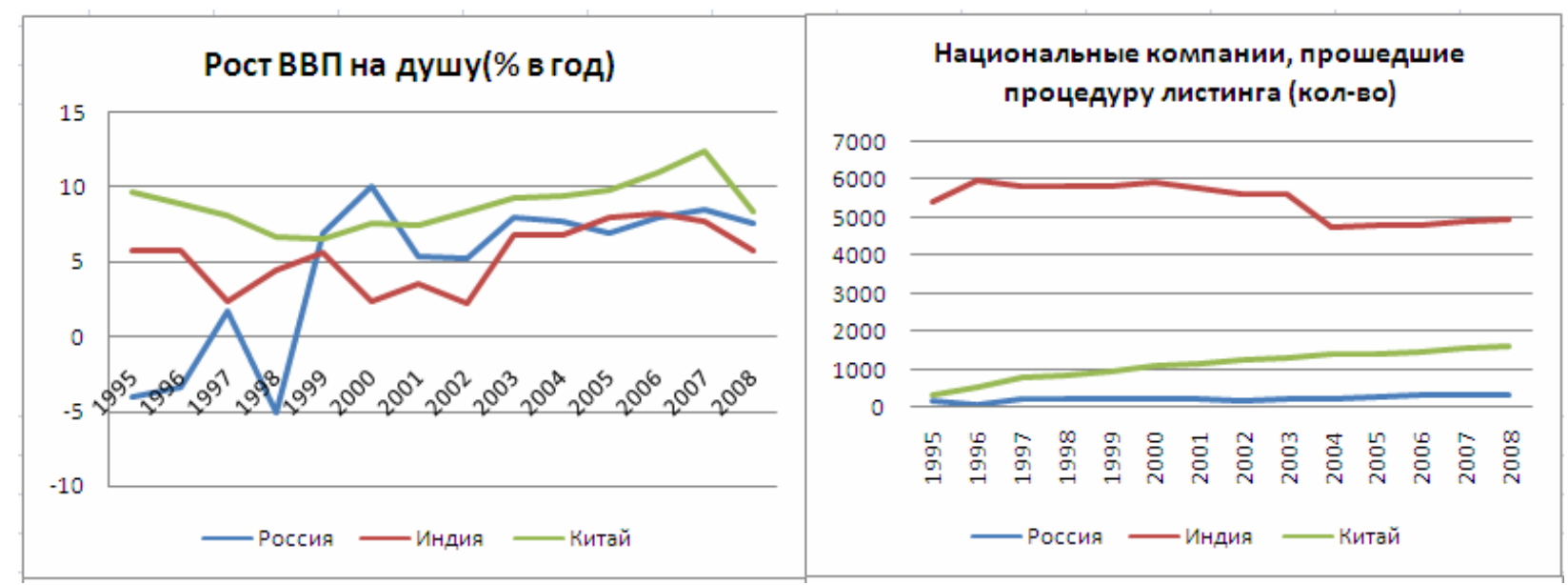

Рис. 1. Макроэкономические показатели России, Индии, Китая в 1995-2008 гг.

Источник: база данных Worldbank, расчеты авторов.

На фондовом рынке не произошло изменений, свидетельствующих о структурных сдвигах, которые необходимо учесть в эконометрической модели (рис. 2). Рисунок 2 показывает, что объем торгов как в Китае, так и в Индии в период 1997-1999 гг. изменялся по траектории предыдущего тренда, без взлетов или падений. Рыночная капитализация (в \% от ВВП) значительно уменьшилась в Индии в 1998 г., но затем продолжила свой рост. Рисунок 2 иллюстрирует гораздо большее падение рыночной капитализации в России в 1998 $\Gamma$.

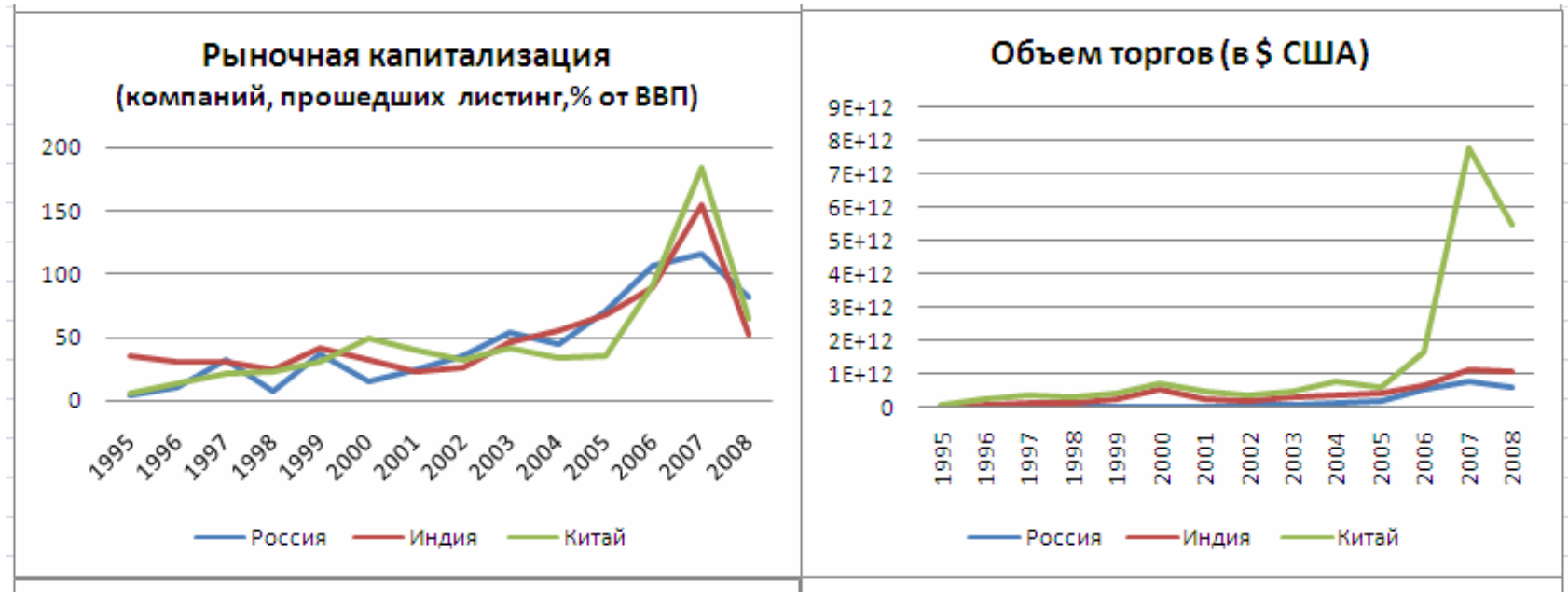

Рис. 2. Рыночная капитализация и объем торгов на фондовом рынке России, Индии, Китая в 1995-2008 гг.

Источник: база данных Worldbank, расчеты авторов.

Российская экономика пережила дефолт августа 1998 г. Из 409 наблюдений по российским компаниям только 8\% наблюдений приходится на период до 1998 г. включительно, поэтому отследить эффект влияния кризиса на дивидендную политику российских компаний не удастся.

Чтобы отследить общее возможное влияние кризиса на дивидендную политику всего 
пула стран, модели будут оцениваться по двум периодам: 1995-1998 гг. и 1999-2008 гг.

Для отслеживания влияния событий в мировой экономике в 2008 г., для 2008 г. будет введена фиктивная (дамми) переменная.

Можно отметить, что в период после 1999 г. (рис. 1-3) динамика развития все трех стран очень схожа. Несмотря на абсолютное превосходство Индии по числу компаний, прошедших листинг на фондовой бирже, рыночная капитализация этих компаний (в \% от ВВП) находится на том же уровне, что и в России и Китае.

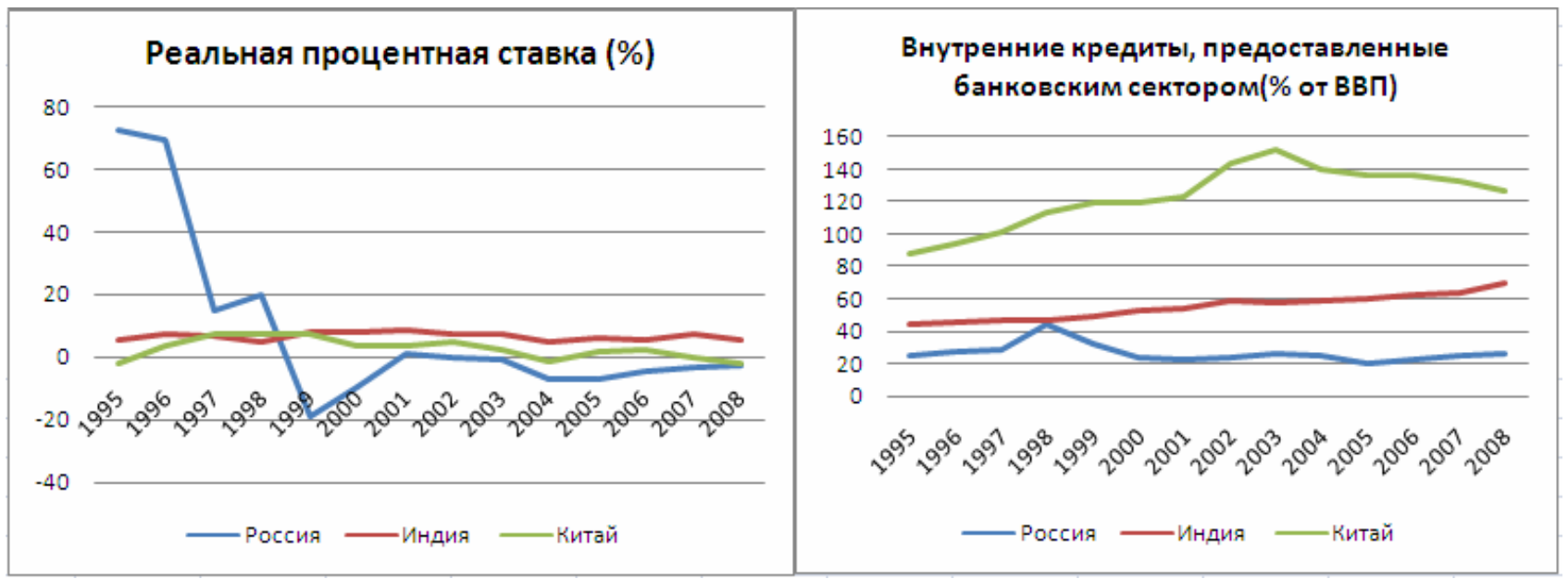

Рис. 3. Реальная процентная ставка и объем кредитования в России, Индии, Китае в $1995-2008$ гг.

Источник: база данных Worldbank, расчеты авторов.

Низкая реальная процентная ставка в Китае и высокие объемы кредитования по сравнению с Россией и Индией (рис. 3) могут иллюстрировать относительную доступность кредита в Китае, которая в свою очередь может стимулировать компании к более высоким выплатам дивидендов. Это связано с тем, что в случае выплаты части нераспределенной прибыли в форме дивидендов компания может взять кредит для финансирования своего роста.

Подтверждением данного факта может быть коэффициент отношения дивидендных выплат к активам компании и коэффициент выплаты дивидендов, который представлен на рисунке 4 (коэффициент выплаты дивидендов был рассчитан только для компаний с положительными прибылями). 
Дивиденды/активы компании

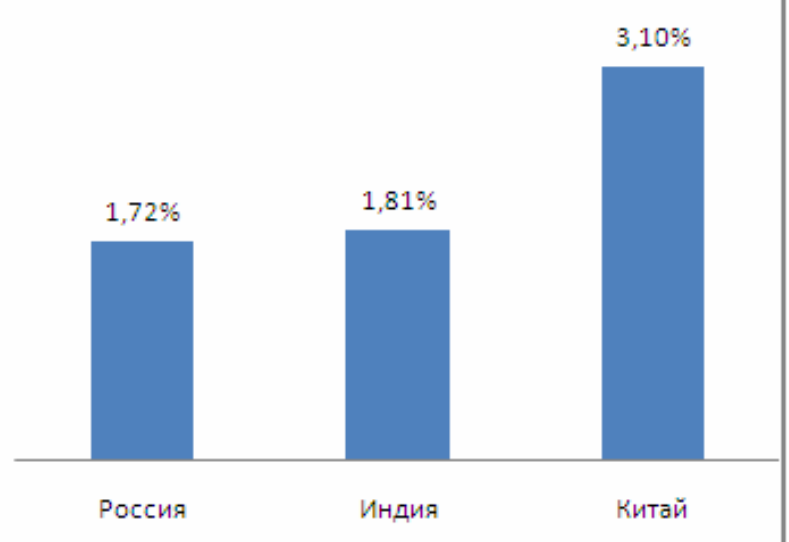

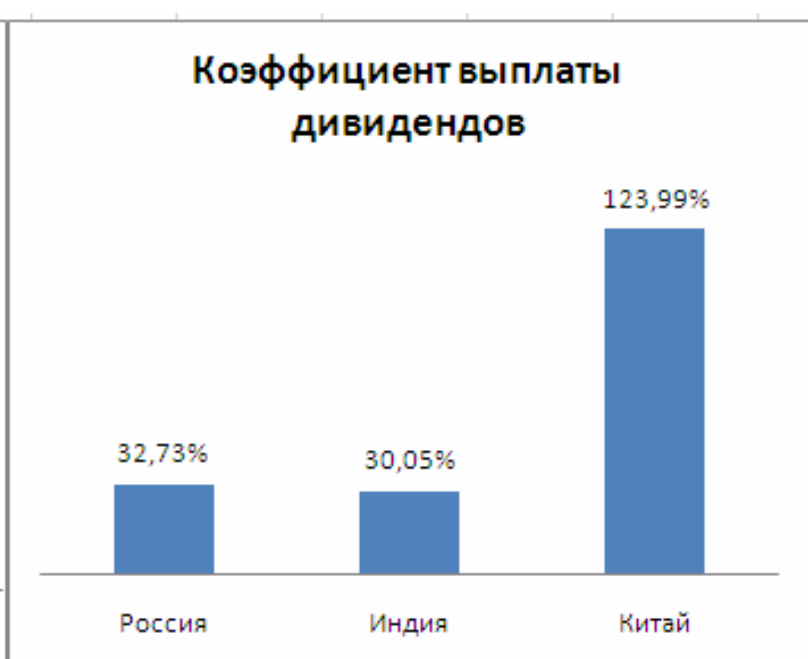

Рис. 4. Коэффициент отношения дивидендов к активам компании и коэффициент выплаты дивидендов в России, Индии, Китае в 1995-2008 гг.

Источник: база данных Compustat, расчеты авторов.

В США коэффициент выплаты дивидендов составляет 33\% [Aivazian et al., 2003]. Как мы видим, в России и Индии (в среднем за период с 1995-го по 2008 г.) этот показатель находится на уровне США.

Китайские компании выплачивают дивиденды в больших размерах, чем их нераспределенная прибыль. Данный факт может объясняться тем, что китайские компании, даже в случае неудачных проектов, не хотят снижать уровень дивидендных выплат, чтобы не посылать негативных сигналов рынку. Более подробно к исследованию и объяснению данного факта мы вернемся в ходе дальнейшего эмпирического анализа.

Если рассматривать не весь период, а разделить его на период до и после кризисов, то разница между коэффициентом дивидендов и активами компании в этот период незначительна, коэффициент выплаты дивидендов, напротив, изменился кардинально (рис. $5)$.

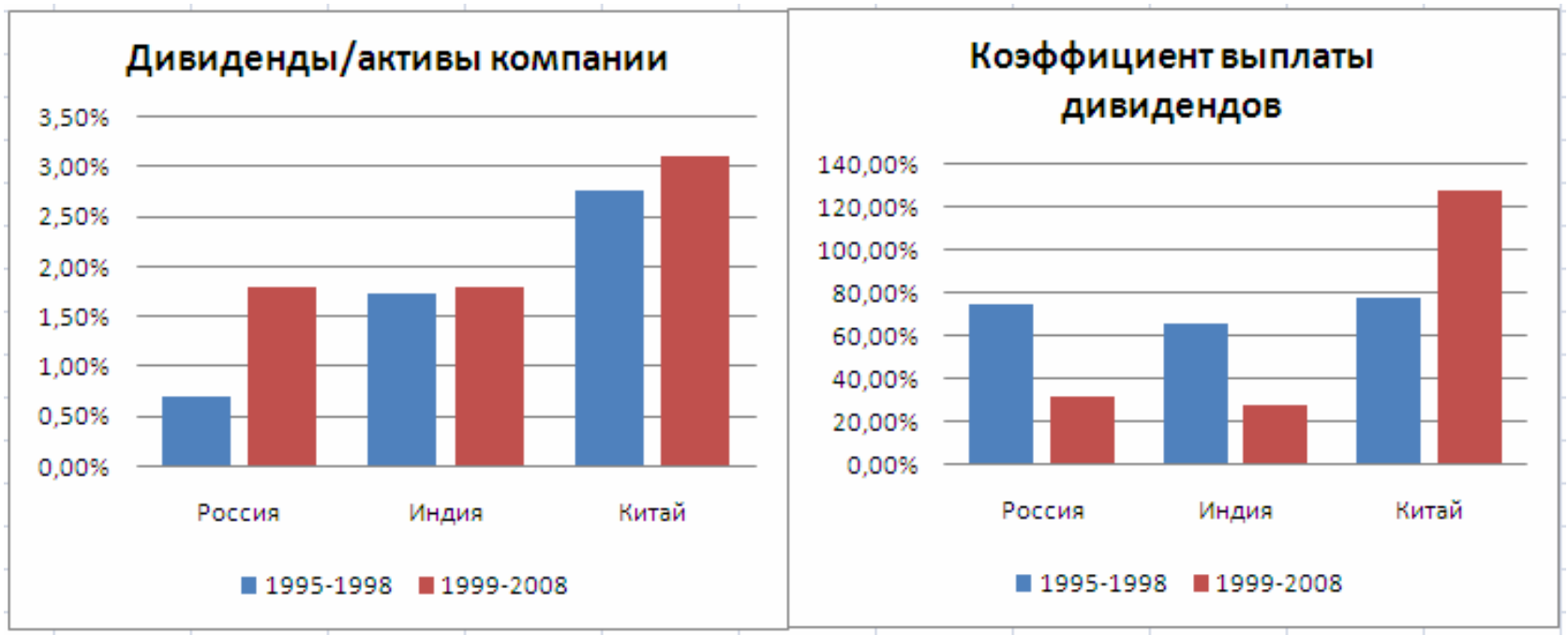

Рис. 5. Коэффициент отношения дивидендов к активам компании и коэффициент выплаты дивидендов в России, Индии, Китае в 1995-1998 гг., 1999-2008 гг.

Источник: база данных Compustat, расчеты авторов.

В Китае в 2008 г. произошел очень большой скачок коэффициента выплаты 
дивидендов. С $78 \%$ в 2007 г. до 287\% в 2008-м. Без учета 2008 г. средний коэффициент дивидендных выплат среди компаний с положительными прибылями составил уже не 127 , а 105\% за период с 1999-го по 2007 г. Столь резкое изменение коэффициента дивидендных выплат в Китае во многом связано с уменьшением прибылей компаний по итогам 2008 г. Нежелание китайских компаний снижать абсолютную сумму дивидендов к выплате, несмотря на факт снижения прибыли, говорит о возможной зависимости дивидендов текущего года от предыдущего даже в большей степени, чем от прибыли. Данный факт может являться подтверждением теории использования дивидендной политики в качестве сигнальной для рынка.

В Китае с 2008 г. произошли изменения в налоговом законодательстве, согласно которым в целом было увеличено налоговое бремя на иностранные компании, осуществляющие бизнес в Китае. Значительно более высокий коэффициент дивидендных выплат в Китае может объясняться тем интересным фактом, что в этой стране для предприятий с иностранным капиталом дивиденды налогом не облагаются, что является наименее затратным для иностранных инвесторов способом вывода прибыли из компании. Налог на дивидендные выплаты в Китае составляет 20\%, а подоходный налог является прогрессивным и изменяется в диапазоне от 5 до $45 \%$.

Большие различия в колебаниях коэффициента выплаты дивидендов в до- и посткризисный период, от изменений в коэффициенте отношения дивидендов к активам компании, иллюстрируют значительную чувствительность дивидендов к прибыли. Рисунок 5 позволяет предположить, что и само значение этой чувствительности разное в Китае и в России с Индией. Прояснить этот вопрос позволит оценка модели Линтера, которая отслеживает степень влияния предыдущих дивидендных выплат и текущего уровня прибыли на текущий уровень дивидендных выплат.

Интересным фактом является то, что, в отличие от Китая и Индии, в России после кризиса соотношение дивидендов и активов выросло в три раза, достигнув уровня Индии. Это связано с наибольшим относительным шоком в период кризиса и структурными изменениями в экономике после кризиса. Увеличение склонности к выплатам может говорить о начавшихся позитивных тенденциях, связанных с корпоративным управлением, необходимости сформировать имидж компании для привлечения новых инвестиций. Учитывая, что крупные компании также стали выходить на мировые фондовые рынки, наличие дивидендной истории также оказывало влияние на их конкурентоспособность и котировки.

Во всех трех странах дивидендные выплаты за период 1995-2008 гг. претерпели определенные изменения, что говорит о целесообразности более детального изучения дивидендной политики в России, Индии и Китае. Россия, Индия и Китай по-разному отреагировали на внешние шоки, поэтому имеет смысл оценивать не только общую выборку развивающихся стран, но и отдельные модели по каждой стране, чтобы выявить наличие потенциальных принципиальных различий в детерминантах дивидендных политик между ними.

\section{Определение зависимой переменной}

Суммируя многочисленные исследования, посвященные дивидендной политике, мы видим, что авторы используют три разных прокси для дивидендной политики фирмы.

Пожалуй, самой популярной переменной является коэффициент выплаты дивидендов (dividend payout ratio); в расчете этой переменной участвует прибыль компании, которая на развивающихся рынках может быть отрицательной. По этой причине мы не будем использовать данную прокси в первой фазе исследования.

В качестве прокси для дивидендной политики авторы также используют коэффициент отношения дивидендных выплат к активам компании (dividend-to-total-assets measure) и дивидендную доходность. 
Дивидендная доходность в случае годовых данных может рассчитываться как отношение дивиденда на акцию к средней цене акции (между самой высокой и низкой ценой года). Учитывая достаточно высокие колебания на фондовых рынках развивающихся стран, среднее самой высокой и низкой цены года, ровно как и цена закрытия, не могут служить адекватной оценкой цены за столь длинный период наблюдения. Айвазян и др. [Aivazian et al., 2003] отмечают недостаток дивидендной доходности, как прокси для дивидендной политики. Авторы говорят, что дивидендная доходность отражает ценовые эффекты, которые находятся вне контроля менеджмента.

В силу всего вышеупомянутого в качестве зависимой переменной будет использоваться коэффициент отношения дивидендных выплат к активам компании.

\section{Макрофакторы и дивидендная политика}

Изменения в дивидендной политике, проиллюстрированные рисунком 5, могли произойти под влиянием многочисленных факторов. Одно из первых предположений состоит в том, что на дивидендную политику компании оказывают влияние не только внутренние характеристики фирмы, но и среда, в которой компания существует.

Определенные макрохарактеристики страны должны оказывать влияние на дивидендную политику. К таким характеристикам могут быть отнесены: уровень развития корпоративного управления в стране, правовой режим в ней, уровень коррупции, ставка подоходного налога и налога на доходы от прироста капитала, уровень развития банковского сектора и доступность кредита, реальная процентная ставка и темп роста ВВП.

Статистика по уровню коррупции в стране, рейтингу уровня развития финансового сектора, рейтингу ориентированности законодательства на развитие бизнеса присутствует в базах данных Всемирного банка, однако отсутствует по России, Индии и Китаю (либо имеется только за один год).

Наличие данных о корпоративных и индивидуальных налогах, а также реальной процентной ставке в странах выборки позволяет нам протестировать следующие гипотезы.

H1. С увеличением налогового бремени в стране уровень выплачиваемых дивидендов снижается.

Во всех странах, доходы, получаемые от дивидендов, облагаются индивидуальным (подоходным) налогом. В случае если индивидуальный налог растет собственники компании в альтернативу требованиям о выплате дивидендов будут искать другие пути изъятия прибыли из компании.

Увеличение корпоративного налога уменьшает размер остатка нераспределенной прибыли, из которой выплачиваются дивиденды.

H2. Реальная процентная ставка отрицательно связана с уровнем выплачиваемых дивидендов.

Данное предположение объясняется тем, что нераспределенная прибыль и кредитные средства являются субститутами при финансировании инвестиций. Увеличение реальной процентной ставки в стране снижает кредитные возможности компании, что может заставить ее снизить или отказаться от выплаты дивидендов в случае необходимости финансировать инвестиции.

\section{Внутренние детерминанты дивидендной политики компании}

Следующие гипотезы касаются детерминантов дивидендной политики компании, если абстрагироваться от ее принадлежности к какой-то конкретной стране.

Опираясь на теоретические предпосылки, можно сформулировать следующие гипотезы для эмпирического исследования.

H3. Увеличение рентабельности компании приводит $\kappa$ увеличению уровня выплачиваемых дивидендов (более рентабельные компании платят более высокие 
дивиденды).

Signaling и maturity hypothesis по-разному трактуют влияние увеличения дивидендов на динамику будущих прибылей. Согласно сигнальной модели, изменение дивидендов говорит об изменении ожиданий менеджеров относительно будущих прибылей и рентабельности фирмы. На развивающихся рынках должна доминировать сигнальная модель, потому что компании в целом имеют больше инвестиционных возможностей и переживают бурную стадию роста, соответственно связь между дивидендами и будущими прибылями положительная.

$\mathrm{B}$ качестве прокси-переменной для уровня рентабельности взят ROA, соответственно ожидается положительная зависимость между ROA и дивидендами.

H4. Бета компании и размер ее дивидендных выплат имеют отрицательную зависимость.

Связь между снижением систематического риска и увеличением выплат дивидендов согласуется как с signaling, так и с maturity hypothesis.

H5. Компании, имеющие больще возможностей для инвестищий, выплачивают более низкие дивидендьл.

Компании, имеющие привлекательные проекты для инвестиций, предпочтут направить нераспределенную прибыль на инвестиции. Так как финансирование инвестиций из нераспределенной прибыли обойдется компании дешевле, чем внешнее финансирование. Согласно pecking order theory (теории порядка финансирования), наиболее выгодно для компании начинать финансирование с нераспределенной прибыли и лишь затем прибегать к долговому финансированию и дополнительной эмиссии акций.

Market-to-book ratio (MBV) выступает как прокси-переменная для инвестиционных возможностей фирмы. Таким образом, ожидается отрицательная зависимость между Marketto-book ratio и дивидендными выплатами.

Н6. Быстрорастущие компании выплачивают меньший объем дивидендов.

Так как быстрорастущие компании нуждаются в большем объеме средств для финансирования собственно роста, то предположительно они будут выплачивать более низкие дивиденды. В качестве прокси-переменной для темпа роста фирмы будет взят темп роста ее активов. Ожидается отрицательная зависимость между темпом роста активов и дивидендами.

H7. Финансовые ограничения в виде размера долга компании отрищательно сказываются на дивидендной политике.

Чем большая часть прибыли уходит на погашение долга компании, тем меньшая ее часть остается на дивиденды. Ожидается статистически значимая отрицательная зависимость между коэффициентом отношения долга к рыночной стоимости собственного капитала компании (как прокси долговой нагрузки) и размером дивидендов.

Н8. Более крупные компании выплачивают более высокие дивиденды.

Более крупные фирмы уже прошли ту стадию, когда им обязательно нужно расти и инвестировать, что бы остаться на рынке. Предполагается, что у крупных фирм меньше проектов для инвестирования (или, по крайней мере, эти проекты составляют меньшую долю по сравнению с их прибылями), следовательно, у компании более высокие потоки свободных денежных средств и больше возможностей для выплаты дивидендов. В качестве прокси для размера будет выступать натуральный логарифм активов фирмы.

H9. Концентрация собственности оказывает влияние на дивидендную политику.

Говоря о концентрации собственности, можно по-разному интерпретировать направление зависимости. Если собственность слишком сконцентрирована и находится в руках одной семьи или очень ограниченного круга лиц, который при этом может являться менеджментом компании, то в этом случае собственник может искать другие пути, посредством которых можно изъять прибыль из компании с наименьшим налогообложением. Если, наоборот, собственность слишком распылена, то масштабы влияния миноритарных акционеров во многом будут зависеть от качества корпоративного 
управления в компании.

\section{Эмпирический анализ данных}

Все модели будут исследоваться методами панельных данных, в основу которых входит оценка моделей с фиксированным и случайным эффектом. Помимо увеличения количества степеней свободы при работе с панельными данными их преимущество состоит в возможности отследить наличие индивидуальных эффектов компаний при формировании дивидендной политики, что невозможно при оценивании перекрестных или временных выборок.

В начале анализа тестировались гипотезы Н3-H9 по общему пулу стран за весь промежуток времени. Часть предполагаемых независимых переменных не оказала статистически значимого влияния на дивидендную политику. В таблице 1 приведены результаты итоговой модели.

Таблица 1.

Модель с фиксированным эффектом

\begin{tabular}{|c|c|c|c|}
\hline \multicolumn{2}{|c|}{$\begin{array}{c}\text { Коэффициент отношения дивидендных выплат к } \\
\text { активам компании }\end{array}$} & \multicolumn{2}{|c|}{$\begin{array}{c}\text { Модель } 1 \\
\text { (4816 наблюдений) }\end{array}$} \\
\hline & & Коэффициент & $\begin{array}{l}\text { Стандартная } \\
\text { ошибка }\end{array}$ \\
\hline Рентабельность & ROA & 0,001 & $(0,00009)^{* * *}$ \\
\hline Бета & & $-0,002$ & $(0,0009)^{*}$ \\
\hline $\begin{array}{l}\text { Ln (Отношение долга к рыночной } \\
\text { стоимости собственного капитала) }\end{array}$ & $\begin{array}{c}\text { Ln }(\mathrm{D} / \mathrm{E}) \\
\text { (market value } \\
\text { of equity) }\end{array}$ & $-0,001$ & $(0,0006)^{* *}$ \\
\hline Количество акционеров & & $8,24 * 10^{-6}$ & $\left(4,60 * 10^{-6}\right) * * * *$ \\
\hline Ln (Активы компании) & & 0,004 & $(0,0007)^{* * *}$ \\
\hline Ln (Темп роста активов) & & $-0,002$ & $(0,0003) * * *$ \\
\hline $\begin{array}{c}1998 \text { (бинарная переменная, } \\
\text { принимает значение } 1 \text { в } 1998 \text { году и } \\
\text { 0 в остальные периоды времени) }\end{array}$ & & $-0,005$ & $(0,0026)^{*}$ \\
\hline Константа & & $-0,015$ & $(0,025)$ \\
\hline
\end{tabular}

* Коэффициент значим на 5\% уровне.

** Коэффициент значим на $1 \%$ уровне.

*** Коэффициент значим на $0,1 \%$ уровне.

**** Коэффициент значим на $10 \%$ уровне.

Для модели 1 статистика Хаусмана принимает значение 213.19 с остаточной вероятностью $\mathrm{P}>\mathrm{X}^{2}=0,00$, что позволяет нам отвергнуть нулевую гипотезу в пользу альтернативной и принять модель с фиксированным эффектом.

Для модели, оцененной по общей выборке стран, получено, что возможности роста, выраженные отношением рыночной стоимости компании к ее балансовой стоимости, не оказывают статистически значимого влияния на дивидендную политику в развивающихся странах. Однако стоит заметить, что в этих странах фондовый рынок также находится на стадии своего становления и развития, соответственно цена акции может еще не в полной мере отражать истинную информацию о компании; более того, для расчета рыночной стоимости компании использовалось среднее самой высокой и никой цены акции, что также могло оказать искажающее влияние на прокси-переменную, использованную в модели, учитывая высокие колебания цен акций на фондовых рынках развивающихся стран.

У компаний всех стран наблюдались изменения в дивидендной политике в 1998 г., 
когда из-за влияния кризиса компании выплатили меньший объем дивидендов.

Рентабельность, систематический риск компании, долговая нагрузка, концентрация собственников, размер и темпы роста компании оказывают влияние на дивидендную политику компаний, знаки соответствуют предположениям, выдвинутым при описании рабочих гипотез.

Большинство исследований по развивающимся рынкам при наличии данных по нескольким странам объединяют их в один пул. Во многом это вызвано тем, что данные доступны по ограниченному количеству компаний и объединение всех стран в один пул увеличивает количество доступных степеней свободы при оценивании моделей. Однако учитывая наличие потенциальных существенных межстрановых различий в дивидендной политике, выявленных в ходе дескриптивного анализа в главе 2, целесообразным представляется более детальное изучение дивидендной политики каждой конкретной страны пула. А именно России, Индии и Китая.

Учитывая наличие кризисов, а также многочисленные изменения в странах в посткризисный период, выборка будет разделена на два периода: 1995-1998 гг. и 1999_ 2008 гг.

В докризисный период по странам имеется очень незначительное количество наблюдений, поэтому для периода с 1995-го по 1998 г. обе страны будут объединены в один пул. Количество наблюдений в посткризисный период позволяет оценивать модель для каждой страны отдельно.

В докризисный период также были оценены модели с фиксированным и случайным эффектом. Статистика Хаусмана составила 6,17 с остаточной вероятностью $\mathrm{P}>\mathrm{X}^{2}=0,5205$, что позволяет с уверенностью принять модель со случайным эффектом. Результаты оценивания данной модели приведены в таблице 2.

Таблица 2.

Модель со случайным эффектом 1995-1998 гг.

\begin{tabular}{|c|c|c|c|}
\hline \multirow{2}{*}{$\begin{array}{c}\text { Коэффициент отношения дивидендных выплат к } \\
\text { активам компании }\end{array}$} & \multicolumn{2}{|c|}{$\begin{array}{c}\text { Модель } 2 \\
\text { (47 наблюдений) }\end{array}$} \\
\cline { 3 - 4 } & ROA & 0,001 & $\begin{array}{c}\text { Стандартная } \\
\text { ошибка }\end{array}$ \\
\hline Рентабельность & & 0,003 & $(0,0004)^{* *}$ \\
\hline Бета & Коэффициент & $(0,0020)$ \\
\hline $\begin{array}{c}\text { Ln (Отношение рыночной } \\
\text { стоимости собственного капитала к } \\
\text { его балансовой стоимости) }\end{array}$ & Ln (M/B) & 0,0007 & $(0,0008)$ \\
\hline $\begin{array}{c}\text { Ln (Отношение долга к рыночной } \\
\text { стоимости собственного капитала) }\end{array}$ & $\begin{array}{c}\text { Ln (D/E) } \\
\text { (market value } \\
\text { of equity) }\end{array}$ & $-0,00009$ & $(0,0024)$ \\
\hline Ln (активы компании) & & $-0,004$ & $(0,0006)$ \\
\hline Ln (Темп роста активов) & & $-0,0009$ & $(0,0402)^{*}$ \\
\hline Константа & & 0,077 & \\
\hline
\end{tabular}

* Коэффициент значим на 5\% уровне.

** Коэффициент значим на $1 \%$ уровне.

В докризисный период на дивидендную политику влияла только рентабельность компании. Состояние неуверенности в завтрашнем дне, неразвитость фондового рынка, кредитных институтов и законодательной базы объясняет незначимость остальных факторов, таких как систематический риск, размер, темпы и возможности роста компании, а также ее долговая нагрузка при определении дивидендной политики компании.

По результатам теста Хаусмана был сделан выбор в пользу модели со случайным 
эффектом. Данный выбор говорит нам о том, что все отклонения в дивидендной политике от средней тенденции по стране объясняются случайными факторами, а не индивидуальностью и определенными характеристиками фирмы.

Далее для посткризисного периода пошагово будет изучено влияние макрофакторов и внутренних характеристик на дивидендную политику компании

Для отслеживания влияния макрофакторов на дивидендную политику были протестированы гипотезы Н1- 2 .

Модель с фиксированным эффектом (1999-2008)

Таблица 3.

\begin{tabular}{|c|c|c|}
\hline $\begin{array}{c}\text { Коэффициент отношения дивидендных } \\
\text { выплат к активам компании }\end{array}$ & \multicolumn{2}{|c|}{ Модель 3} \\
$(6582$ наблюдений)
\end{tabular}

** Коэффициент значим на $1 \%$ уровне.

*** Коэффициент значим на $0,1 \%$ уровне.

Предельная ставка налогообложения как корпоративного, так и индивидуального, а также реальная ставка процента имеют отрицательную статистически значимую зависимость с объемом выплачиваемых дивидендов в период после 1998 г., в докризисный период количество наблюдений недостаточно для оценки данной спецификации модели.

Та как мы имеем дело с панельными данными, то были оценены модели с фиксированным и случайным эффектом. Для того чтобы понять, какие эффекты присутствуют в модели, был проведен тест Хаусмана.

Для модели 3 статистика Хаусмана принимает значение 91,39 с остаточной вероятностью $\mathrm{P}>\mathrm{X}^{2}=0,00$, что позволяет нам отвергнуть нулевую гипотезу в пользу альтернативной и принять модель с фиксированным эффектом.

Отрицательная зависимость между реальной процентной ставкой и объемом дивидендов объясняется достаточно легко: чем выше процентная ставка, тем дороже компании привлекать дополнительные средства для новых проектов. На развивающихся рынках большая часть компаний переживает активную фазу роста и постоянно нуждается в новых капиталовложениях. Соответственно, если заемное финансирование привлекать дорого, то компания сокращает выплату дивидендов и использует освободившуюся нераспределенную прибыль на финансирование своего роста.

Несмотря на то что в академической литературе большое внимание уделено влиянию налогов на дивиденды, эмпирические результаты свидетельствуют об относительной незначимости этого фактора при принятии менеджерами компаний решения о дивидендах [Brav et al., 2005].

Результаты модели 3 говорят об отрицательной зависимости между общим налоговым бременем в стане и объемом выплачиваемых дивидендов. Здесь стоит обратить внимание на величину коэффициентов перед независимыми переменными, отвечающими за налоги. Так, например, одновременное повышение обоих налогов на $5 \%$ приведет всего к полупроцентному снижению коэффициента выплаты дивидендов.

Для анализа межстрановых различий в посткризисный период сначала будет оценена модель Линтнера, после чего детерминанты дивидендной политики России, Индии и Китая 
будут рассмотрены в более широком контексте.

Рисунок 5 проиллюстрировал значительную чувствительность дивидендов к прибыли и позволил предположить, что и само значение этой чувствительности разное в Китае и России с Индией. Объяснить эти различия позволит оценка модели Линтнера, где дивиденд на акцию в текущий год объясняется предыдущим уровнем дивидендных выплат и прибылью в текущий период (в описанную спецификацию будет добавлена фиктивная переменная для 2008 г., которая принимает значение 1 в 2008 г. и 0 в остальные периоды времени).

Модель оценена в посткризисный период после 1998 г.

Для каждой страны модель оценена отдельно, в целях выявления межстрановых различий.

Таблица 4.

Модель с фиксированным эффектом

\begin{tabular}{|c|c|c|c|c|c|c|}
\hline \multirow{3}{*}{ Дивиденд на акцию } & \multirow{2}{*}{\multicolumn{2}{|c|}{$\begin{array}{l}\text { Модель } 4 \\
\text { Россия } \\
2 \text { наблюдения) }\end{array}$}} & \multirow{2}{*}{\multicolumn{2}{|c|}{$\begin{array}{c}\text { Модель } 5 \\
\text { Индия } \\
4514 \text { наблюдений) }\end{array}$}} & \multicolumn{2}{|c|}{ Модель 6} \\
\hline & & & & & $\begin{array}{r}\mathrm{K} \\
(4704 \mathrm{H} \\
\end{array}$ & $\begin{array}{l}\text { Китай } \\
\text { аблюдения) }\end{array}$ \\
\hline & $\begin{array}{c}\text { Коэффи } \\
\text { циент }\end{array}$ & $\begin{array}{c}\text { Стандарт } \\
\text { ная ошибка }\end{array}$ & $\begin{array}{c}\text { Коэффиц } \\
\text { иент }\end{array}$ & $\begin{array}{c}\text { Стандартная } \\
\text { ошибка }\end{array}$ & $\begin{array}{c}\text { Коэффи } \\
\text { циент }\end{array}$ & $\begin{array}{c}\text { Стандартная } \\
\text { ошибка }\end{array}$ \\
\hline $\begin{array}{c}\text { Дивиденд на акцию в } \\
\text { предыдущий год }\end{array}$ & 0,971 & $(0,078)^{* * *}$ & $-0,015$ & $(0,015)$ & 0,583 & $(0,017)^{* * *}$ \\
\hline $\begin{array}{c}\text { Прибыль на акцию в } \\
\text { текущий год }\end{array}$ & 0,010 & $(0,008)$ & 0,114 & $(0,003)^{* * *}$ & 0,136 & $(0,006)^{* * *}$ \\
\hline $\begin{array}{c}2008 \text { (бинарная } \\
\text { переменная, принимает } \\
\text { значение } 1 \text { в } 2008 \text { г. и } 0 \text { в } \\
\text { остальные периоды } \\
\text { времени) }\end{array}$ & 0,172 & $(0,086)^{*}$ & $-0,009$ & $(0,007)$ & 0,019 & $(0,001)^{* * *}$ \\
\hline Константа & 0,038 & $(0,016)^{*}$ & 0,036 & $(0,003)^{* * *}$ & 0,007 & $(0,0005)^{* * *}$ \\
\hline
\end{tabular}

* Коэффициент значим на $5 \%$ уровне.

** Коэффициент значим на $1 \%$ уровне.

*** Коэффициент значим на $0,1 \%$ уровне.

Единственная страна, в которой модель Линтнера работает на 100\%, то есть все факторы являются статистически значимыми, это Китай. Китай действительно реализует политику частичного приспособления, то есть компании определяют выплату, исходя из двух факторов:

1) текущая прибыль;

2) предыдущие дивиденды, которые позволяют обеспечить относительно стабильное планирование выплат, а также сгладить сигнальные шоки, посылаемые на рынок, в случае, если не оправдались ожидания акционеров.

Что касается Индии и России, то каждая из стран, согласно модели, использует только один из двух факторов для определения дивидендной политики. В случае Индии - это прибыль на акцию, то есть компании Индии предпочитают платить фиксированную часть прибыли на акцию в качестве дивидендов, не обращая внимания на сигнальную составляющую, которая также может интерпретироваться как составляющая гаранта плательщикам.

Что касается России, то дивиденды в текущий год зависят только от дивидендов в предыдущий период и не зависят от прибыли в текущий период. Это может говорить о наличии у российских компаний целевого коэффициента выплаты дивидендов. Производя 
выплаты дивидендов, российские компании не хотят отклоняться от намеченного тренда. Отсутствие статистически значимой связи дивидендов и прибыли, однако, может говорить о большой заинтересованности компаний в положительном сигнализировании рынку. Однако в период экономического роста рост прибыли может быть выше, чем прирост дивидендов, и тогда данная политика, наоборот, направлена на сохранение части нераспределенной прибыли внутри компании. В периоды экономического спада, наоборот, данная политика опасна тем, что у компании может возникнуть необходимость прибегнуть к заемному финансированию в случае недостаточности прибыли для выплаты запланированных дивидендов.

Для учета данного фактора первоначальная модель была расширена дополнительной независимой переменной, а именно реальной процентной ставкой в стране.

Таблица 5.

Модель с фиксированным эффектом

\begin{tabular}{|c|c|c|c|c|c|c|}
\hline \multirow{3}{*}{$\begin{array}{c}\text { Дивиденд на } \\
\text { акцию }\end{array}$} & \multirow{2}{*}{\multicolumn{2}{|c|}{$\begin{array}{c}\text { Модель } 7 \\
\text { Россия } \\
\text { (202 наблюдения) }\end{array}$}} & \multirow{2}{*}{\multicolumn{2}{|c|}{$\begin{array}{c}\text { Модель } 8 \\
\text { Индия } \\
2 \text { наблюдения) }\end{array}$}} & \multicolumn{2}{|c|}{ Модель 9} \\
\hline & & & & & $(4704 \mathrm{r}$ & $\begin{array}{l}\text { итай } \\
\text { блюдения) }\end{array}$ \\
\hline & $\begin{array}{c}\text { Коэффиц } \\
\text { иент }\end{array}$ & $\begin{array}{c}\text { Стандартная } \\
\text { ошибка }\end{array}$ & \begin{tabular}{|c|} 
Коэффи \\
циент
\end{tabular} & $\begin{array}{c}\text { Стандартная } \\
\text { ошибка }\end{array}$ & $\begin{array}{c}\text { Коэффиц } \\
\text { иент }\end{array}$ & $\begin{array}{c}\text { Стандартная } \\
\text { ошибка }\end{array}$ \\
\hline $\begin{array}{c}\text { Дивиденд на } \\
\text { акцию в } \\
\text { предыдущий год }\end{array}$ & 0,996 & $(0,076)^{* * *}$ & Нет & Нет & 0,570 & $(0,017)^{* * *}$ \\
\hline $\begin{array}{c}\text { Прибыль на акцию } \\
\text { в текущий год }\end{array}$ & Нет & Нет & 0,099 & $(0,002) * * *$ & 0,134 & $(0,006) * * *$ \\
\hline $\begin{array}{c}2008 \text { (бинарная } \\
\text { переменная, } \\
\text { принимает } \\
\text { значение } 1 \text { в } 2008 \\
\text { г. и } 0 \text { в остальные } \\
\text { периоды времени) }\end{array}$ & 0,168 & $(0,087) * * * *$ & Нет & Нет & 0,015 & $(0,001)^{* * *}$ \\
\hline $\begin{array}{c}\text { Реальная } \\
\text { процентная ставка } \\
\text { в стране }\end{array}$ & 0,003 & $(0,003)$ & $-0,004$ & $(0,002)^{*}$ & $-0,0009$ & $(0,0002) * * *$ \\
\hline Константа & 0,059 & $(0,020)^{* * *}$ & 0,062 & $(0,013)^{* * *}$ & 0,009 & $(0,0006) * * *$ \\
\hline
\end{tabular}

* Коэффициент значим на $5 \%$ уровне.

** Коэффициент значим на $1 \%$ уровне.

*** Коэффициент значим на $0,1 \%$ уровне.

**** Коэффициент значим на $10 \%$ уровне.

Для России реальная процентная ставка статистически незначима при определении объемов выплачиваемых дивидендов, что говорит о том, что даже внешние неблагоприятные условия не оказывают влияния на принятую политику. Это также можно объяснить тем, что роль рыночной процентной ставки в России все еще несравнимо мала относительно роли данного определяющего показателя для компаний Китая и Индии, ведь реальная процентная ставка в России зачастую бывает отрицательной. 


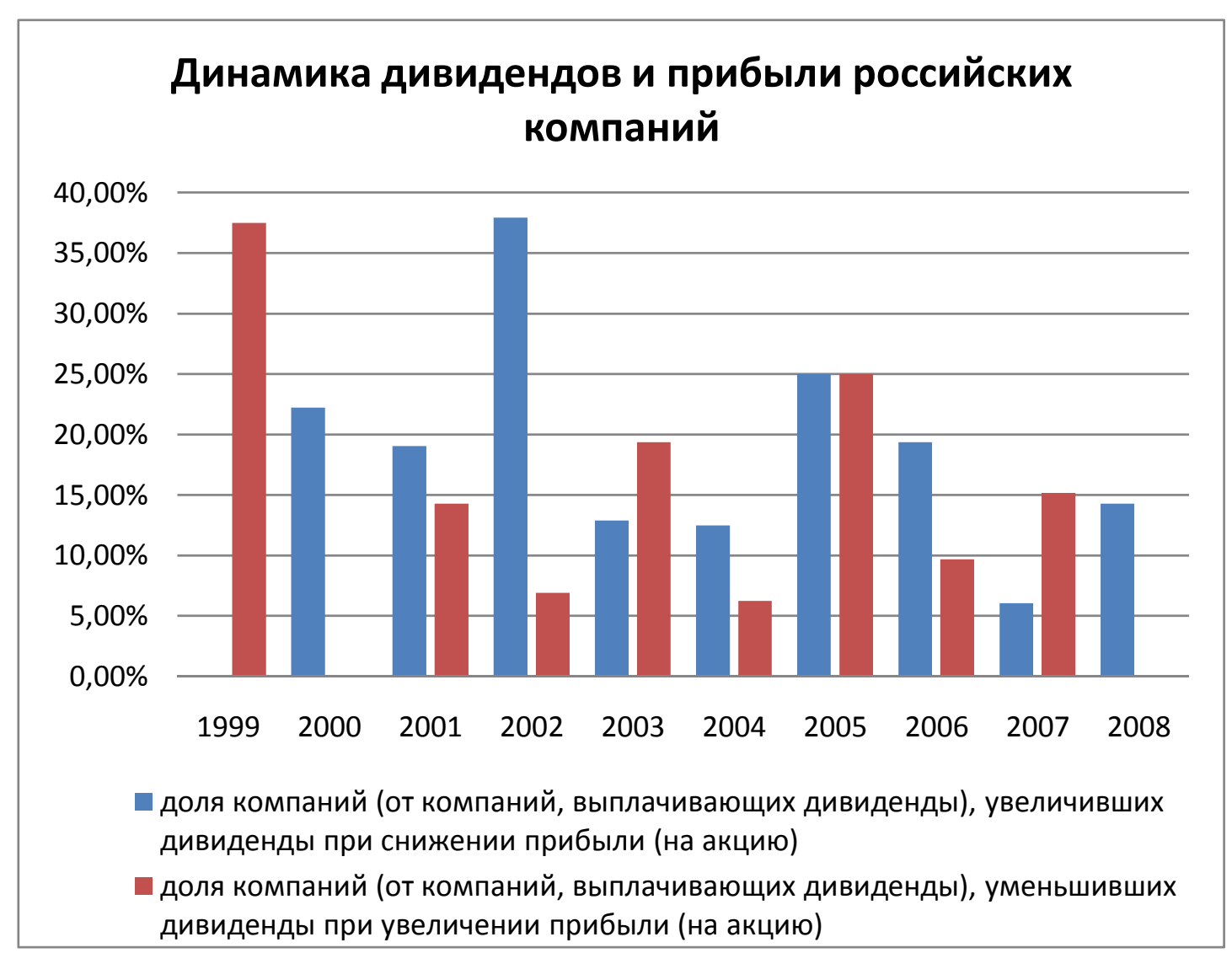

Рис. 6. Динамика дивидендов и прибыли российских компаний в 1999-2008 гг.

Эмпирические результаты говорят о том, что текущая прибыль и процентная ставка не влияют на дивидендную политику, но при этом нельзя говорить о стабильности и предсказуемости дивидендной политики российских компаний.

Рисунок 6 показывает, что каждый год можно наблюдать компании, у которых динамика дивидендов и прибыли противоположна (при увеличении прибыли компания снижает дивиденды и увеличивает их при снижении прибыли). Рисунок 6 не позволяет говорить о ярко выраженном нежелании российских компаний идти на снижение дивидендов.

Индийские компании, напротив, определяя уровень выплачиваемых дивидендов, ориентируются только на текущую прибыль, но не на прошлогодний уровень дивидендов.

Реальная процентная ставка также оказывает влияние на объемы выплачиваемых дивидендов, при увеличении реальной процентной ставки компании снижают дивиденды.

В Китае дивиденды в текущий период зависят как от прибыли в этот период, так и от дивидендов в прошлый период. Реальная процентная ставка также имеет статистически значимое влияние на дивиденды китайских компаний.

По результатам теста Хаусмана, в случае всех трех стран делается выбор в пользу модели с фиксированным эффектом. Это значит, что в каждом конкретном случае отклонения дивидендной политики фирмы от средней тенденции в стране объясняются индивидуальностью фирмы, а не случайными факторами, как это происходит в модели со случайным эффектом. Это позволяет говорить о наличии определенной дивидендной политики у фирм на таких развивающихся рынках, как Россия, Индия и Китай. Однако в каждой стране дивидендная политика имеет свои отличительные черты, как это демонстрируют результаты моделей; более того, говоря о наличии дивидендной политики, мы не можем говорить о стабильной дивидендной политике. В контексте России можно говорить о том, что компания относительно легко может пойти на снижение дивидендов, но при этом из 43 компаний, выплачивающих дивиденды в период с 1999-го по 2008 г., только 3 компании вообще прекратили выплаты дивидендов, 2 компании не выплачивали Выпуск \#4(12), 2009 
дивиденды только 1 год за весь период и 2 компании приостанавливали выплату на 2 года и более, возобновив ее в последующем. Данный факт позволяет говорить о наличии дивидендной политики в том контексте, что, однажды приняв решение о выплате дивидендов, компания будет стараться придерживаться этого решения в будущем и акционеры могут ожидать регулярной выплаты дивидендов. При этом не стоит ожидать регулярного индексирования дивидендов или 100\%-ного совпадения динамики дивидендов и прибыли российских компаний, так как текущая прибыль российских компаний не является статистически значимым фактором при определении уровня дивидендных выплат. В Индии, где основой дивидендной политики является текущая прибыль, более 45\% компаний, выплачивающих дивиденды, приостанавливали их выплату на один год или более. В Китае зависимость текущих дивидендных выплат от их предыдущего значения говорит о более стабильной дивидендной политике. Так, в Китае количество компаний, которые выплачивали дивиденды, а затем приостанавливали выплаты на один год или более, составляет около $20 \%$.

Из эмпирических результатов также представляет интерес значение доли дисперсии, которая приходится на индивидуальные характеристики фирмы и представлена в таблице 6.

Таблица 6.

Дисперсия, объясняемая индивидуальными эффектами компаний

\begin{tabular}{|l|l|l|l|}
\hline & Россия & Индия & Китай \\
\hline rho & $21 \%$ & $34 \%$ & $34 \%$ \\
\hline
\end{tabular}

В Индии и Китае 34\% колебаний дивидендной политики объясняются именно индивидуальностью фирмы. В России этот показатель ниже и составляет $21 \%$ - это значит, что для российских компаний больший процент вариации объяснятся внешними, в том числе случайными, факторами. (Не стоит путать данную вариацию со значением R2 в простой линейной регрессии. Приведенные в таблице 6 вариации не говорят нам о доле дисперсии, которую удалось объяснить оцененной моделью, они говорят о доле дисперсии, которая объясняется именно индивидуальными характеристиками объекта. Данные вариации возможно рассчитать, только оценивая модели с панельными данными.)

Модель Линтнера доказала существенность различий в детерминантах дивидендной политики между странами, поэтому дальнейший анализ внутренних факторов, определяющих дивидендную политику компаний в посткризисный период (1999-2008 гг.), будет идти в разрезе каждой страны в отдельности.

\section{Оценка внутренних детерминантов дивидендной политики компании}

Тестируя гипотезы Н3-H8, для каждой развивающейся страны в отдельности были получены следующие результаты: 
Модель с фиксированным эффектом (1999-2008 гг.)

\begin{tabular}{|c|c|c|c|c|c|c|}
\hline \multirow{2}{*}{$\begin{array}{c}\text { Коэффициент } \\
\text { отношения } \\
\text { дивидендных выплат к } \\
\text { активам компании }\end{array}$} & \multicolumn{2}{|c|}{$\begin{array}{c}\text { Модель } 10 \\
\text { Россия } \\
\text { (253 наблюдения) }\end{array}$} & \multicolumn{2}{|c|}{$\begin{array}{c}\text { Модель } 11 \\
\text { Индия } \\
\text { (2774 наблюдения) }\end{array}$} & \multicolumn{2}{|c|}{$\begin{array}{c}\text { Модель } 12 \\
\text { Китай } \\
\text { (3453 наблюдения) }\end{array}$} \\
\hline & $\begin{array}{c}\text { Коэффицие } \\
\text { нт }\end{array}$ & $\begin{array}{c}\text { Стандарт- } \\
\text { ная } \\
\text { ошибка }\end{array}$ & $\begin{array}{c}\text { Коэффиц } \\
\text { иент }\end{array}$ & $\begin{array}{c}\text { Стандарт- } \\
\text { ная } \\
\text { ошибка }\end{array}$ & $\begin{array}{c}\text { Коэффици } \\
\text { ент }\end{array}$ & $\begin{array}{c}\text { Стандарт- } \\
\text { ная } \\
\text { ошибка }\end{array}$ \\
\hline Рентабельность & Нет & Нет & 0,001 & $\begin{array}{c}(0,0001) \\
* * *\end{array}$ & 0,0007 & $\begin{array}{c}(0,0001) \\
* * *\end{array}$ \\
\hline Бета & Нет & Нет & $-0,004$ & $\begin{array}{c}(0,0016) \\
* *\end{array}$ & Нет & Нет \\
\hline $\begin{array}{c}\text { Ln (Отношение } \\
\text { рыночной стоимости } \\
\text { собственного капитала к } \\
\text { его балансовой } \\
\text { стоимости) } \\
\end{array}$ & Нет & Нет & Нет & Нет & Нет & Нет \\
\hline $\begin{array}{c}\text { Ln (Отношение долга к } \\
\text { рыночной стоимости } \\
\text { собственного капитала) }\end{array}$ & Нет & Нет & $-0,003$ & $\begin{array}{c}(0,0009) \\
* * *\end{array}$ & Нет & Нет \\
\hline $\begin{array}{c}\text { Ln (Отношение активов } \\
\text { к рыночной стоимости } \\
\text { собственного капитала) }\end{array}$ & Нет & Нет & Нет & Нет & $-0,002$ & $(0,0007)^{* *}$ \\
\hline $\begin{array}{c}\text { Ln (Количество } \\
\text { акционеров) }\end{array}$ & Нет & Нет & Нет & Нет & Нет & Нет \\
\hline Ln (выручка компании) & Нет & Нет & Нет & Нет & 0,003 & $\begin{array}{c}(0,0006) \\
* * *\end{array}$ \\
\hline Ln (активы компании) & 0,015 & $\begin{array}{c}(0,0031) \\
* * *\end{array}$ & 0,003 & $\begin{array}{c}(0,0014) \\
* *\end{array}$ & Нет & Нет \\
\hline Темп роста активов & $-0,0007$ & $\begin{array}{c}(0,0003) \\
* *\end{array}$ & $-0,005$ & $\begin{array}{c}(0,0015) \\
* * *\end{array}$ & $-0,002$ & $\begin{array}{c}(0,0004) \\
* * *\end{array}$ \\
\hline $\begin{array}{c}2008 \text { (бинарная } \\
\text { переменная, принимает } \\
\text { значение } 1 \text { в } 2008 \text { г. и } 0 \text { в } \\
\text { остальные периоды } \\
\text { времени) }\end{array}$ & Нет & Нет & $-0,008$ & $\begin{array}{c}(0,0018) \\
* * *\end{array}$ & 0,005 & $\begin{array}{c}(0,0009) \\
* * *\end{array}$ \\
\hline Константа & $-0,309$ & $\begin{array}{c}(0,0669) \\
* * *\end{array}$ & 0,063 & $(0,0423)$ & 0,040 & $(0,0286)$ \\
\hline
\end{tabular}

* Коэффициент значим на 5\% уровне.

** Коэффициент значим на $1 \%$ уровне.

*** Коэффициент значим на $0,1 \%$ уровне.

В докризисный период (таблица 2) была принята модель со случайным эффектом. Результат теста Хаусмана в посткризисный период в пользу фиксированных эффектов в каждой из стран дает основания полагать, что существует большая разница в тенденциях до и после кризиса. Значимость фиксированных эффектов каждой из индивидуальных фирм объясняет большую часть отклонения каждого конкретного наблюдения от средней тенденции по стране дивидендной политикой фирмы.

В России в посткризисный период на дивидендную политику влияют размер компании и темп роста ее активов. Стабильные больше компании будут выплачивать больше дивидендов, чем маленькие и быстрорастущие. Рентабельность компании не оказывает 
влияния на размер выплачиваемых дивидендов, что согласуется с результатами динамической модели (таблица 4), где прибыль российских компании также не оказывала влияния на их дивидендную политику. Незначимость рычага компании согласуется с нестабильной динамикой дивидендных выплат в России, компания скорее снизит дивиденды, чем прибегнет к заемному финансированию, для поддержания уровня дивидендов при недостаточности объемов нераспределенной прибыли. Отсутствие статистически значимой связи между систематическим риском компании и ee Market-to-book (оотношение рыночной стоимости собственного капитала к его балансовой стоимости) иллюстрирует отсутствие отлаженного механизма передачи фондовым рынком информации о компании и ее изменениях в России по сравнению с развитыми рынками.

Количество акционеров выступало в качестве прокси для концентрации собственников; статистически значимой связи между концентрацией собственников и размерами дивидендов получено не было. При наличии данных эту переменную было бы интересно посмотреть в паре с прокси для уровня корпоративного управления в компании, чтобы отследить возможность миноритарных акционеров лоббировать свои интересы. Общепризнанных индексов и рейтингов корпоративного управления, охватывающих большую часть российских компаний, на данный момент не существует, а составление такого индекса в рамках данной работы невозможно, так как в данной работе рассматриваются также обширные выборки еще двух развивающихся рынков, а именно Индии и Китая.

На дивидендные выплаты индийских компаний положительно влияет рентабельность и размер компании. Положительная связь между рентабельностью и дивидендами говорит в пользу доминирования сигнальной модели в Индии. Согласно сигнальной модели, изменение дивидендов говорит об изменении ожиданий менеджеров относительно будущих прибылей и рентабельности фирмы. В период бурного роста компании сигнализируют о своих перспективах выплатой дивидендов. Данная зависимость также согласуется с динамической моделью (таблица 4), где прибыли компании оказывались более значимым фактором, чем поддержание предыдущего тренда, при принятии решения о выплате дивидендов в Индии.

Подтверждая выдвинутые гипотезы, систематический риск, темпы роста и долговая нагрузка компании отрицательно связаны с объемом выплачиваемых дивидендов.

Для китайских компаний примечателен тот факт, что размер компании имеет положительную связь с объемом дивидендных выплат, но статистически значимой прокси является выручка компании, а не размер ее активов. Та же ситуация наблюдается с финансовыми ограничениями компании. Отношение долга к рыночной стоимости собственного капитала не имеет статистически значимой связи с объемом выплаты дивидендов. Прокси для долговой нагрузки, выраженное рычагом компании, имеет статистически значимую связь с дивидендами. С чем может быть связан данный факт? Коэффициент отношения долга к стоимости собственного капитала компании более чувствителен к изменению долга. Если долговая нагрузка лишь отчасти влияет на выплату дивидендов, т.е. при значительном изменении долга дивиденды меняются незначительно (например, компании активно финансируют свой рост за счет заемных средств), динамика рычага в этом случае в большей степени будет согласовываться с динамикой дивидендных выплат, что и обуславливает его значимость.

По результатам оценивания всех моделей были получены существенные различия как во времени, так и между странами. В докризисный период основным драйвером дивидендной политики являлась рентабельность компании, в посткризисный период дивидендная политика на развивающихся рынках России, Индии и Китая определялась более комплексно.

Детерминанты дивидендной политики в посткризисный период в каждой стране разные: так, например, рентабельность в Индии значительно больше влияет на размер выплачиваемых дивидендов, чем в Китае, и при этом совсем незначима в России. 
Систематический риск компании оказывает влияние только на дивидендную политику индийских компаний. Финансовые ограничения компании, в форме размера ее долга, снижают дивидендные выплаты в Индии и Китае и при этом не оказывают влияния на дивидендную политику российских компаний. Этот вывод согласуется с результатами расширенной модели Линтнера, где реальная процентная ставка в стране оказалась значимой только для Китая и Индии. Это значит, что Индия и Китай, финансируя свои инвестиции за счет долга и части нераспределенной прибыли, корректируют свою дивидендную политику при улучшении или ухудшении своих кредитных условий. Размер и темпы роста оказывают значимое влияние на дивидендную политику всех трех стран.

Для всех стран в посткризисный период была одобрена модель с фиксированным эффектом, что говорит о том, что в каждом конкретном случае отклонения дивидендной политики фирмы от средней тенденции в стране объясняются индивидуальностью фирмы, а не случайными факторами, как в случае с моделью со случайным эффектом. Это позволяет говорить о том, что компании России, Индии и Китая выплачивают дивиденды не случайно, а формируют именно дивидендную политику компании.

\section{Заключение}

В данной работе методами панельного анализа данных изучалась дивидендная политика России, Индии и Китая в период с 1995-го по 2008 г.

К основным результатам данной работы можно отнести следующие:

- Дивидендная политика компаний в до- и посткризисные периоды (дефолт в России в 1998 г., азиатский кризис 1997-1999 гг.) определяется различными факторами. В докризисный период дивидендная политика определялась рентабельностью компании и носила более комплексный характер в посткризисный период. Более того, в докризисный период все отклонения в дивидендной политике от средней тенденции по стране объясняются случайными факторами, а не индивидуальностью и определенными характеристиками фирмы.

- Реальная процентная ставка и общее налоговое бремя в Индии и Китае отрицательно влияют на объем выплачиваемых дивидендов. В России индивидуальные налоги не влияют на объем выплачиваемых дивидендов.

- Детерминанты дивидендной политики России. Индии и Китая в каждом случае индивидуальны, за исключением размера компании и темпов ее роста.

- В России дивиденды в текущем году зависят только от дивидендов в предыдущем периоде и не зависят от прибыли в текущем периоде. Это в определенной мере свидетельствует о наличии у российских компаний именно дивидендной политики, а не случайных выплат акционерам. Российские компании относительно легко могут пойти на снижение дивидендов, но при этом решение о приостановке выплаты дивидендов на один год или более принимало только около $16 \%$ выборки. На дивидендную политику компаний в России также положительно влияет размер компании и темп роста еe активов. Стабильные крупные компании будут выплачивать больше дивидендов, чем маленькие и быстрорастущие.

- Индийские компании, напротив, определяя уровень выплачиваемых дивидендов, ориентируются только на текущую прибыль, но не на прошлогодний уровень дивидендов, что говорит о нестабильности дивидендной политики индийских фирм. Помимо рентабельности положительное влияние на дивидендную политику в Индии оказывает размер компании. Систематический риск, темпы роста и долговая нагрузка компании отрицательно связаны с объемом выплачиваемых дивидендов.

- В Китае дивиденды в текущем периоде зависят как от прибыли в текущем периоде, так и от дивидендов в прошлом периоде. Размер компании также положительно влияет на дивидендную политику, при этом в Китае, при определении размера фирмы, значима именно выручка компании, а не величина ее активов. Долговая 
нагрузка накладывает ограничения на дивидендную политику китайских компаний.

- В Индии и Китае $34 \%$ колебаний дивидендной политики объясняются именно индивидуальностью фирмы $(34 \%$ из всей объясненной моделью дисперсии приходится на индивидуальные эффекты). В России этот показатель ниже и составляет $21 \%$; это значит, что для российских компаний больший процент вариаций объяснятся внешними, в том числе случайными, факторами.

Отличительной чертой данной работы является также наличие базы данных в период до 2008 г. включительно, что позволило получить наиболее актуальные результаты.

Полученные результаты позволяют потенциальным акционерам, нацеленным на получение дивидендного дохода, понять дивидендную политику компаний России, Индии и Китая и принять решение об инвестициях.

\section{Список литературы}

1. Adaoglu, C. (2000), Instability in the Dividend Policy of the Istanbul Stock Exchange (ISE) Corporations: Evidence from an Emerging Market, Emerging Markets Review, 1 (2000) $252-70$.

2. Aivazian, V., Booth, L., and Cleary, S. (2003), Do Emerging Market Firms Follow Different Dividend Policies from U.S. Firms? Journal of Financial Research, 26 (2003) $371-87$.

3. Allen, F., and Michaely, R. (2003), Payout policy. In: Constantinides, G., Harris, M., Stulz, R. (Eds.), Handbook of Economics. North-Holland, Amsterdam, p. 337-430.

4. Baker, H.K., Veit, E.T., and Powell, G.E. (2001), Factors influencing dividend policy decisions of Nasdaq firms, Financial Review, Vol. 36, 3 (2001) 19-37.

5. Black, F. (1976), The Dividend Puzzle, Journal of Portfolio Management 2, 2 (1976) 5-8.

6. Brav, A., Graham, J., Harvey, C., and Michaely, R. (2005), Payout policy in the 21st century, Journal of Financial Economics 77 (2005) 483-527.

7. Cheng, L. T. W., Fung Hung-Gay and Leung, T. Y. (2008), What Drives the Cash Dividend Policy of the Poorly Performing Firms in Hong Kong?, Review of Pacific Basin Financial Markets and Policies, Vol. 11, 3 (2008) 347-361.

8. DeAngelo, H., DeAngelo, L., and Skinner, D.J. (2004), Are dividends disappearing? Dividend concentration and the consolidation of earnings, Journal of Financial Economics, 72 (2004) 425-456.

9. DeAngelo, H. and DeAngelo, L. (2006), The irrelevance of the MM dividend irrelevance theorem, Journal of Financial Economics, 79 (2006) 293-316.

10. Easterbrook, F. (1984), Two agency cost explanations of dividends, American Economic Review, 74 (1984) 650-659.

11. Fama, E.F., and French, K.R. ( 2001), Disappearing Dividends: Changing Firm Characteristics or Lower Propensity to Pay?, Journal of Financial Economics 60, 1 (2001) $3-43$.

12. Grullon, G. and Michaely, R. (2000), The Information Content of Share repurchase programs, Working paper, Cornell University, Ithaca NY.

13. Grullon, G., Michaely, R. and Swaminathan, B. (2002), Are dividend changes a sign of firm maturity?, The Journal of Business, 75, 3 (2002) 387-424.

14. Jensen, M.C., and Meckling, W.H. (1976), Theory of the Firm: Managerial Behaviour, Agency Costs and Ownership Structure, Journal of Financial Economics 3,4 (1976) 305360.

15. John, K. and Williams, J. (1985), Dividends, Dilution, and Taxes: A Signaling Equilibrium, Journal of Finance, 40, 4 (1985) 1053-1070.

16. La Porta, R., Lopez-de-Silanes, F., Shleifer, A., and Vishny, Robert W. (1998), Law and finance, Journal of Political Economy 106 (1998)1113-1155.

17. La Porta, R., Lopez-de-Silanes, F., Shleifer, A., and R. Vishny (2000), Agency problems 
and dividend policies around the world, Journal of Finance LV, 1 (2000) 1-33.

18. Lintner, J. (1956), Distribution of Incomes Corporations Among Dividends, Retained Earnings and Taxes, American Economic Review 46, 2 (1956) 97-113.

19. Miller, M.H., and Modigliani, F. (1961), Dividend Policy, Growth and the Valuation of Shares, Journal of Business 34, 4 (1961) 411-433.

20. Miller, Merton, and Rock, Kevin (1985), Dividend Policy Under Asymmetric Information, Journal of Finance, 40, 4 (1985) 1031-1051.

21. Mitton, T. (2004), Corporate governance and dividend policy in emerging markets, Emerging Markets Review 5 (2004) 409- 426.

22. Naceur, Samy Ben, Goaied Mohamed and Belanes Amel (2006), On the Determinants and Dynamics of Dividend Policy, International Review of Finance, 6,1-2 (2006) 1-23.

23. Nohel, T. and Tarhan, V. (1998), Share Repurchases and Firm Performance: New Evidence on the Agency Costs of Free Cash Flow, Journal of Financial Economics, 49 (1998) 187222.

24. Omran M., Pointon J. (2004), Dividend Policy, Trading Characteristics and share prices: Empirical evidence from Egyptian firms, International Journal of Theoretical and Applied Finance, 7, 2 (2004)121-133.

25. Rajan, Raghuram, and Luigi, Zingales (1995), What do we know about capital structure? Some evidence from the international data, Journal of Finance 50 (1995) 1421-1460.

26. Reddy, Y. Subba, Rath S. (2005), Disappearing Dividends in Emerging Markets? Evidence from India, Emerging Markets Finance and Trade, 41, 6 (2005) 58-82.

27. Sawicki, J. (2009), Corporate governance and dividend policy in Southeast Asia pre- and post-crisis, The European Journal of Finance, 15,2 (2009) 211-230.

28. Stephens, Clifford, and Michael, Weisbach (1998) Actual share reacquisitions in open market repurchases programs, Journal of Finance, 53, 1 (1998) 313-333.

29. Vermaelen, T. (1981), Common Stock Repurchases and Market Signaling: An Empirical Study, Journal of Financial Economics, 9, 2 (1981) 138-183. 